\title{
Historical medicine: Biblical and talmudic surgery and surgical practice
}

\section{Estēe Dvorjetski*}

Professor, School of History, Philosophy and Culture, Oxford Brookes University, United Kingdom

Zinman Institute of Archaeology, University of Haifa, Israel
Received: 04 December, 2020

Accepted: 19 December, 2020

Published: 21 December, 2020

*Corresponding authors: Estēe Dvorjetski, Professor, School of History, Philosophy and Culture, Oxford Brookes University, United Kingdom, Tel: +972-48769406, +972-549911016;

E-Mail: edvorjetski@brookes.ac.uk

Zinman Institute of Archaeology, University of Haifa, Haifa 3498838, Israel,

E-mail: esteed@research.haifa.ac.il

https://www.peertechz.com

\section{Check for updates}

\begin{abstract}
The legacy of surgery in ancient Jews included those who cared for the wounds and injuries. In light of this they were awarded the title of experts, ummanim. The aim of the paper is to introduce the history of the craft of surgery from biblical times throughout the talmudic period focusing on historical and medical perspectives. Along the way, the surgical progress made a creative advancement of anatomical studies.
\end{abstract}

\section{Introduction}

The main sources of our knowledge of ancient Jewish medicine are the Bible and the talmudic corpus. The Talmud is a compendium of commentaries and elaborations on biblical teachings. It includes snatches on jurisprudence, history, ethics, mathematics, philosophy, astronomy, theology, medicine, and botany. It was compiled by a number of Jewish scholars as a tradition transmitted orally for centuries and finally placed in definite literary form at the end of the 5th century as a collective labour of many generations. In contradistinction to the written Mosaic Law in the five books of the Pentateuch (Torah) [1], the talmudic corpus consists of the law as transmitted by verbal tradition (Mishnah), with its several interpretations and commentaries (Gemara). The Mishnah, comprised of an annotated version of the Oral Law, was first put into editing around $200 \mathrm{CE}$ [2], and was followed by the Tosefta [3], which was a further expansion on the Mishnah. Together, the Mishnah and the Gemara are referred to as the Talmud. There are two Talmuds. The Jerusalem Talmud [JT] was created around $400 \mathrm{CE}$ in the Land of Israel under Roman and Byzantine rule [4], while the Babylonian Talmud [BT] was formulated around 600 CE in Babylonia, mostly under Sassanid rule [5]. The talmudic corpus created in the Land of Israel also included Midrashim (5th-6th centuries CE) [6]. As guides to an understanding of stages in the development of medical lore, the talmudic statements have great historical value. Their medical knowledge was based not only on hypotheses and traditions, but also on observation, dissection, and experimentation. Its most interesting feature of the talmudic corpus is the light it throws upon later Jewish anatomy and surgery, and upon the knowledge of post-mortem appearances [7-11].

The author checked the original texts in biblical Hebrew and Aramaic as she is expert in these ancient languages. In addition, the author also checked all translations from these languages into English. These checked translations appear in references [1-6].

\section{Discussion}

Surgery was commonly practised throughout the ancient world, and it was not isolated from practical medicine in ancient Jewish lore. A search of the Bible brings to light occasional references to surgery, but the authors of the Scriptures evidently had no intent to instruct or expand knowledge in the art, and produced nothing resembling a surgical treatise $[12,13]$.

In Genesis 50:2, Joseph commanded his Egyptian servants the physicians to embalm his father Jacob for burial. The Ebers Papyrus (1550 BCE) [14], reinforced by other authentic records, demonstrates that the Egyptians had specialists, who had studied anatomy and practised human dissection for preparation of mummies. Embalming was just one step in the careful process of preserving a body. The key steps of mummification were removal of the brain, the internal organs, 
putting the body into a natural salt to dry it out, coating the body in the embalming recipe to kill bacteria and to seal it and wrapping the body in linen [15-17].

The only surgical operations mentioned in the Bible are circumcision and castration, the former being mandatory - a covenant made with Abraham (Genesis 17:10-11), and the latter being forbidden (Deuteronomy 23:2). Moses, when in Egypt, probably gained knowledge of Egyptian surgery and health customs, which he subsequently imparted to the Hebrews. In Acts 7:22 we learn that he had familiarity with such Egyptian customs: 'And Moses was learned in all the wisdom of the Egyptians'. A wall relief discovered at Saqqara, from the tomb of Ankh-ma-Hor dating back to the 6th Dynasty (2345-2181 BCE), indicating that the rite of circumcision was an old and established one. It depicts a circumciser performing the operation on a young man, who is standing remarkably still. Perhaps he had been given dose of pain reliever before his surgery [17]. Surgeons may have performed this procedure as well as priests, but not always. In Exodus 4:25, we have the first biblical record of a flint used in circumcision, 'to cut off the foreskin of her son'. Flint, however, was not necessarily the usual instrument of circumcision, for Zipporah was forced to act quickly to stave off God's wrath and she probably availed herself of whatever was handiest. It is highly probable that metal knives were also employed. It should be remembered that the manufacture and use of brass and iron implements were known (Genesis 4:22). That it was a painful operation can readily be discerned, for so great was the weakness and pain of the circumcised adults even on the third day following circumcision (Genesis 34:24-25). In another occasion, when God was referring to those males recently born in the desert who had not been circumcised, he ordered Joshua: 'Make flint knives and circumcise the Israelites again' (Joshua 5:2). The technique practised is unknown. In addition, the text of Isaiah 3:7 demonstrates the presence of a wound dresser or possibly surgeon. The Hebrew word which is translated as 'healer' literally signifies 'one who binds up' [4]. At times, the treatment of wounds is mentioned metaphorically (Isaiah 1:6; Ezekiel 16:10) [18-20].

The surgeon appears to have been familiar in Israel. The Bible describes the death of King Ahab, where no treatment of a wound was even considered. No one considered the use of a surgeon to arrest the bleeding (I King 22:34-37) [21]. There would seem, in fact, to have been some kind of medical or surgical centre in northern Israel in the Valley of Jezreel. For when King Joram of Israel was badly wounded in a battle against the Arameans at Ramoth Gilead, 'King Joram went back to be healed in Jezreel from the wounds which they had given him'. Apparently there were also visiting hours in the hospital, for in the same verse we read: 'Ahaziah King of Judah went down to see Joram in Jezreel because he was a patient there' (II Kings 8:29) [22]. The resulting conclusion is that wounds themselves were rarely described, and when they were it was because the individual was a central figure in the event [23].

Surgical cases then, as now, were considered more dangerous and, consequently, brought greater fame to the successful physician. The woman bound by the spirit of her infirmity (Luke 13:11-17), was a case of senile kyphosis; while Lazarus was the typical beggar outcast from society, who can be seen at any of our city dispensaries suffering from varicose ulceration (Luke 14:20). That the priests possessed some accurate surgical knowledge cannot be disputed, for the rite of circumcision was delayed if the child was jaundiced, a fact that would indicate that they appreciated the danger of haemorrhage in such conditions. The Hebrew materia medica consisted of balm of Gilead, myrrh, cinnamon, aloes, spikenard, calamus, camphor, cassia, and mandrake. Folklore medicine attributed healing virtues to saliva, and the first aid to the injured rendered by the good Samaritan, when he poured oil and wine into the sufferer's wounds, was certainly surgically orthodox [24]. A further instance of surgical accident may be seen in the case of Malcus, whose right ear was cut off (John 18:10). No doubt, Peter aimed the sword at the head of the high priest's servant with the intention of doing more serious damage, but in the event only the pinna was severed. If complete from the adjacent tissues took place, the healing which ensured was strictly miraculous, since neither ancient nor modern surgery would avail under such circumstances [25].

Surgery in the time of the talmudic era was not considered to be its own subspecialty and was practiced by general physicians. The high degree to which surgery had been developed may be seen both from operations and their modus operandi [26]. The surgeon wore a leather apron (Mishnah, Kelim, 26:5), strapped the patient tightly to the table (Tosefta, Sheqalim, 1:6), and used several compartments such as knives, scissors, needles, forceps, and drill, which he kept in a special box (Mishnah, Kelim, 16:8; Midrash Exodus Rabbah, 26:2, 27:9; BT, Sanhedrin 84b; BT, Avodah Zarah 28b; BT, Shabbat 108b) [13,27]. Cranial plates, uterine speculum, crutches, and various types of prostheses were in use. Venesection, sewing-up of wounds, trephinations of the cranium, splenectomies, amputations, catheterizations of the throat, fractures and even plastic surgery are described in the Talmud [7,9,28-30]. The surgeon opened abscesses skillfully (Tosefta, Eduyot, 1:8), opened the cranium with drill (Mishnah, Oholot, 2:3), splited the brain (Midrash Leviticus Rabbah, 22:3), and closed the defect with pumpkin peel (Tosefta, Oholot, 2:6) $[13,27,29,31]$.

Among the operations mentioned in the Talmud were smoothing a fissured penis (BT, Yevamoth 75b), dissections of a corpse of a prostitute (BT, Bekhorot 45a), and a human scalp (BT, Hullin 123a). The removal of the spleen was carried out without fatal results (BT, Sanhedrin 21b; BT, Avodah Zarah 44a), plastic surgery and castration of the throat (BT, Hullin 43b), cleft lip [32], caesarean section (BT, Arakhin 7a) [33], insertion of artificial teeth (BT, Shabbat 65a), an imperforate anus of a new-born (BT, Sanhedrin 129b), and intubation of the larynx upon animals (BT, Hullin 57a-b) are described. In case of loss of substance of the cranium they used a plate for a plastic operation (BT, Ketuboth 43b; BT, Shabbat 66a). They used to bind the abdominal viscera closely together by means of relaxing the abdominal muscles and by closing the wound with sutures (BT, Shabbat 82a) [7,13,26]. 
Biblical medicine created a rational sanitary code and established public health practices. The talmudic corpus provided not only commentaries on biblical hygiene, but also added new instructions with regard to general and personal hygiene and sanitation, which were of vital importance. Thus, hand washing followed surgeries (BT, Pesahim 112a). In the dressing of wounds, the Talmudists warned of touching the wound, because 'the hand causes inflammation' (BT, Avodah Zarah 28b; BT, Shabbat 129a). Abscesses were incised and drained (Mishnah, Eduyot, 2:5; Tosefta, Eduyot, 1:8; BT, Gittin 69b) $[7,9,27]$.

Before attempting the major operations, a sleeping draught [samme de shinta] was administered (BT, Bava Metzia $83 \mathrm{~b}$ ). The value of alcohol as an anesthetic is described in BT, Sanhedrin 43a: ' $\mathrm{He}$ is given a goblet of wine containing a grain of frankincense in order to benimb his senses' [7,34,35]. Sleeping potions were used in the case of an arm amputation (BT, Bava Kamma 85a). An unknown anesthetic sleeping potion is also mentioned in the BT, Bava Metzia 83b in relation to an abdominal operation because of extreme obesity performed upon a patient. He got a potion that induced sleep, taken into a marble house, which provides a hygienic environment as it can easily be cleaned. His abdomen was opened, and many baskets of fat were removed from him. The type of drink used is not indicated nor do the commentaries on the Talmud specify what it may have been $[27,34,36]$.

Among ancient surgical procedures is trephination, also known as craniotomy, in which part of the skull is removed without penetrating the underlying soft tissue of the brain. Various techniques included scraping the bone, cutting a rectangular hole, or boring a hole. The operation was performed to relieve pressure caused by intracranial infection, to extract an object imbedded in the skull, or to provide evil spirits with a means of escape. Evidence is that the patient could survive for some time after the surgery, since there are indications of healing. If necessary, the procedure could be repeated $[22,37,38]$. The most detailed report of a surgical procedure is that of cranial surgery performed to remove a disease called ra'atan (BT, Ketuboth $77 \mathrm{~b}$ ), which is unknown to us $[27,39]$. The Talmud clearly describes a growth or organism present upon the lining membranes of the brain. There is no mention of the intracranial location of the lesion. The marble house was preferred location for the operation. Three hundred cups of a presumable anesthetic solution were then poured over the skull. A drill was then used to open the skull. Four myrtle leaves were added to separate the organism, which could then be removed with forceps. The use of leaves and forceps illustrates the knowledge that damage to the brain itself would result in probable death so that care was taken to leave both the brain and meninges intact $[29,31,40]$. The Roman author Pliny the Elder [41] and the Greek surgeon and pharmacologist Dioscorides [42] document the use of herbal anaesthetics such as opium poppy (Papaver somniferum) syrup, henbane seed extract (Hyoscyamus albus) and mandrake root (Mandragora officinarum) during surgery in the 1st century CE. Pliny maintains that the smell of the leaves caused sleepiness and the ingestion of too much decoction could kill. It is very likely that the same anesthetics were also given in surgeries that took place in the Land of Israel and Babylonia.

Interestingly, it is said about Emperor Titus (39-81 CE), who crushed Jewish rebellion with brutality and burned the Temple of Jerusalem in $70 \mathrm{CE}$, underwent trephination of his cranium for chronic headache (BT, Gittin 56b) [7,43,44]. During this procedure, in which he lost his life, a tumour that resembled a sparrow (passer domesticus) was found. It had a brass-like orange colour and black-grey specks, and weighed about 30g. Another text describes the lesion growth as resembling a dove weighing about 360 g (Midrash Genesis Rabbah, 10:7) $[13,29,40,43]$. Based on the weight and size of such a mass, the differential diagnosis would include a hemangioma, meningioma, and acoustic neuroma [7,29,31].

Surgery was carried out on leprosy patients if their arms or legs were badly disfigured and amputations were performed by the physicians (Mishnah, Kreitut, 3:8) [7]. It is unknown whether any anesthetic was administered before surgery but their limbs were insensitive due to nerve damage as a result of the leprosy. Their stumps were enclosed in linen bandages so that they could move around with a stool attached to their body supported on their arms. Leprous or gangrenous which had been amputated were buried in burial mounds outside the cities which was understood to be highly contagious (Tosefta, Oholot, 16:1; Genesis Rabbah, 60:3; BT, Ketuboth 20b) [7,45-47].

\section{Conclusion}

The familiarity of the ancient Jews with anatomy, physiology, surgery, sleeping draughts, and disinfectants is indeed remarkable. There were operating places with marblepanelled walls. Preventive medicine and heath care of the individual are the major themes in biblical and talmudic sources. Talmudic medicine advanced far above the level of its time. It was based not only on tradition and hypotheses, but also on observation, experimentation, and autopsies upon animals and human beings. The Talmudists demonstrated their power of objective observation, logical analysis and clear vision and advanced the science of pathology [48].

\section{References}

1. The Holy Bible [King James Version] (1611) New York: American Bible society Pub.

2. Danby H (1938) The Mishnah. London: H. Milford Pub.

3. Neusner J (2002) The Tosefta. I-II. Peabody, Mass.: Hendrickson Pub.

4. Neusner J (1982-1991) The Jerusalem Talmud. I-XXXIV, Atlanta GA: Scholars Press.

5. Epstein I [Ed] (1935-1961) The Babylonian Talmud. I-XVIII, London: Soncino Press. Link: http://bit.ly/34sJKzx

6. Freedman H, Simon M (1939-1961) Midrash Rabbah. I-X, London: Soncino Press. Link: http://bit.ly/3arDI5Z

7. Preuss J (1978) Biblical and talmudic medicine (Ed. and Trans. F Rosner) New York: Sanhedrin Press.

8. Kagan SR (1952) Jewish medicine. Boston-Mass.: Medico-Historical Press. 
9. Rosner F (1995) Medicine in the Bible and the Talmud. New Jersey: Ktav Pub.

10. Bernstein A, Bernstein H (1951) Medicine in the Talmud. Calif Med 74: 267 268. Link: https://bit.ly/3p7rSSN

11. Kottek S (2006) Medical interest in ancient rabbinic literature. In: S Safrai, Z Safrai, J Schwartz and PJ Tomson (Ed). The Literature of the Sages. Assen: Fortress: $485-496$

12. Friedenberg ZB (2009) Surgery over the centuries. London: Janus Pub.

13. Rosner F (2000) Encyclopedia of medicine in the Bible and the Talmud Northvale: Jason Aronson Pub.

14. Gordon MB (1941) Medicine among the ancient Hebrews. Isis 33: 454-485. Link: https://bit.ly/37vrqYs

15. Reeves C (1992) Egyptian medicine. Princes Risborough: Shire Press.

16. David RA (Ed) (2008) Egyptian mummies and modern science. Cambridge: Cambridge University Press. Link: http://bit.ly/3nylTop

17. Nunn JF (2002) Ancient Egyptian medicine. London: The British Museum Press.

18. Kottek SS (2003) Medicine in ancient Hebrew and Jewish cultures. In: H Selin (Ed). Medicine across cultures: history and practice of medicine in nonwestern cultures. Boston: Kluwer Pub 305-324. Link: http://bit.ly/3h2CzTP

19. Seeman D (2014) Circumcision in Judaism: the sign of the covenant. Oxford: Oxford University Press. Link: http://bit.ly/3aqiGoA

20. Propp W (1987) The origins of infant circumcision in Israel. Heb Ann Rev 11 355-370. Link: http://bit.ly/3h02zPC

21. Dolev E, Nerubay J (1982) Battle wounds in the Bible. Koroth 8: 35-37.

22. Hardie JB (1966) Medicine and the biblical world. Canad Med Ass J 94: 32-36. Link: http://bit.ly/3mzNp4M

23. Buck A (1917) The growth of medicine from the earliest times to about 1800 New Haven: Yale University Press.

24. Murphy HH (1930) Biblical medicine and hygiene. Can Med Ass J 220: 262264. Link: http://bit.ly/3mCyuXv

25. Harrison RK (1989b) Medicine. In: GA Buttrick (Ed). The interpreter's dictionary of the Bible. III, New York: Abingdon Pub.: 331-334.

26. Bernstein A (1938) The Talmud: a medical Laboratory. Calif West Med J 49: 308-310. Link: http://bit.ly/3axQVu2

27. Loukas M, Bilinsky E, Bilinsky S, Abrahams P, Diamond M, et al. (2011) Surgery in early Jewish history. Clin Anat 24: 151-154. Link: http://bit.ly/3rcQdlz

28. Rosner F (1986) Bloodletting in talmudic times. Bull N Y Acad Med 62: 935 946. Link: http://bit.ly/2KFphQW

29. Tubbs S, Loukas R, Marios S, Mohammadali M, Cohen-Gadol AA, Wellons JC, et al. (2008) Roots of neuroanatomy, neurology and neurosurgery as found in the Bible and Talmud. Neurosurgery 63: 156-163. Link: http://bit.ly/37uhnD3
30. Levinger U, Blickstein I (2000) Surgery in the Talmud. Harefuah 138: 75-77. Link: https://bit.ly/2KIIEsn

31. Weinberg A (2006) A case of cranial surgery in the Talmud. J Hist Neurosci 15 : 102-110. Link: http://bit.ly/34t8WWF

32. Westreich M, Segal S (2000) Cleft lip in the Talmud. Ann Plast Surg 45: 229 237. Link: http://bit.ly/3nCF41Q

33. Lurie S (2006) Vaginal delivery after caesarean delivery in the days of the Talmud (2nd Century BCE-6th Century CE). Vesalius 12: 23-24. Link: http://bit.ly/3myT2A8

34. Rosner F, McCall DD, Berman SJ (1971) Anesthesia in the Bible and Talmud Anesth Analog 50: 298-301. Link: http://bit.ly/3anThf1

35. Bergman N (1998) The genesis of surgical anesthesia. Illinois: Wood LibraryMuseum of Anesthesiology.

36. Kottek SS (1996) On health and obesity in talmudic lore. Isr Med Sci 32: 509510. Link: https://bit.ly/2KiKRLs

37. King PJ, Stager LE (2001) Life in Biblical Israel. Louisville: Knox Press. Link: http://bit.ly/2J7puw6

38. Borowski O (2003) Daily life in biblical times. Leiden: Brill Pub.

39. Rosner F (1993) The illness 'ra'atan' (insect in the brain?). Korot 10: 157-161. Link: http://bit.ly/2Kcpvzs

40. Feinsod M (2010) Neurology in the Bible and the Talmud. In: S Finger, $F$ Boller, KK Thyler (Ed). Handbook of clinical neurology: history of neurology. Edinburgh: Elsevier: 37-47.

41. Pliny the Elder, Historia Naturalis (1958) WHS Jones (Ed). Loeb classical library. London: W. Heinemann Pub.

42. Dioscorides of Anazarbus, De Materia Medica (2005) LY Beck (Ed). Hildesheim: Olms-Weidmann. Link: http://bit.ly/3p6glh3

43. Dan B (2005) Titus's tinnitus. J Hist Neurosci 14: 210-213. Link: http://bit.ly/3augXhV

44. Katz Y (1997) Did a mosquito kill Titus? Harefuah 133: 653-655. Link: http://bit.ly/3axQ5NU

45. Williams GP (2009) A talmudic perspective on Old Testament diseases, physicians and remedies. MA thesis. University of South Africa. Link: http://bit.ly/2J9jy50

46. Dvorjetski E (2011-2012) Diagnosis, prognosis and ways of treatment of 'leprosy' throughout the ages. Koroth 21: 227-254.

47. Medlen LM (1980) Health Care in the Bible and the Talmud. Curationis 3: 2831. Link: http://bit.ly/3mvWHib

48. Dvorjetski E (forthcoming) Archaeological remains of surgical and medical procedure of trephination in the Land of Israel in antiquity.

Copyright: () 2020 Dvorjetski E. This is an open-access article distributed under the terms of the Creative Commons Attribution License, which permits unrestricted use, distribution, and reproduction in any medium, provided the original author and source are credited. 